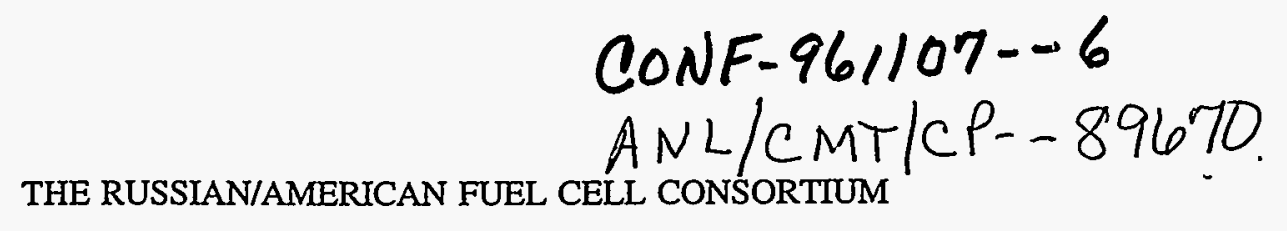

By

A. Sylwester and R. Baker Sandia National Laboratory

P.O. Box 5800

Albuquerque, NM 87185

and

RECEIVED

APR 141997

OSTI

M. Krumpelt

Argonne National Laboratory

Electrochemical Technology Program

9700 South Cass Avenue

Argonne, IL 60439

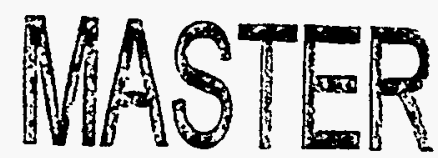

The submitted manuscript has been authored by

a contractor of the U.S. Govemment under

contract No. W-31-109-ENG-38. Accordingly, the

U. S. Govemment retains a nonexclusivo, royalty-

free license to publish or reproduce the published

form of this contribution, or allow others to do so,

for U. S. Government purposes.

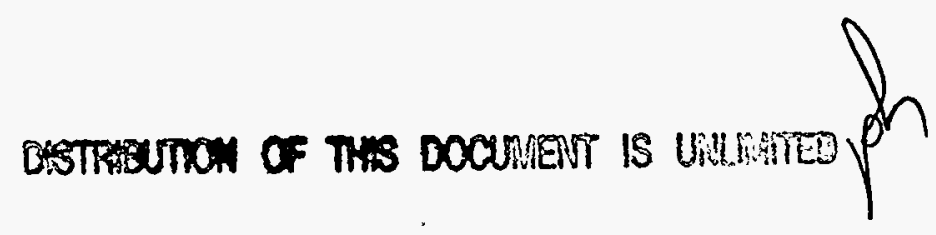

Poster to be presented at Fuel Cell Seminar, Kissimmee, Florida, November 17-20, 1996. 


\section{DISCLAIMER}

Portions of this document may be illegible in electronic image products. Images are produced from the best available original document. 


\title{
THE RUSSIAN/AMERICAN FUEL CELL CONSORTIUM
}

\author{
A. Sylwester and R. Baker \\ Applied Energy Technology Integration \\ Sandia National Laboratory \\ P.O. Box 5800 \\ Albuquerque, NM 87185 \\ M. Krumpelt \\ Argonne National Laboratory \\ 9700 South Cass Avenue \\ Argonne, IL 60439
}

\section{BACKGROUND}

The United States and Russia discovered a mutual interest in fuel cell development during a series of workshops designed to teach entrepreneurial skills to Russian nuclear weapon scientists and engineers to aid them in converting their skill to peaceful applications.

The proposal for a Russian/American Fuel Cell Consortium was initiated at the third workshop held in Livermore, CA, in May 1994. Representatives from U.S. fuel cell industries, U.S. research institutes, Russian institutes and ministries, and U.S. national laboratories attended, including those from GAZPROM, the Russian natural gas company. GASPROM needs to provide power for telemetry, cathodic corrosion protection of gas lines, and gas line pumping power in remote areas, and estimates that it needs approximately seventy thousand 1.5 to $15 \mathrm{KW}$ plants to do so. Since the workshop, several direct working relationships have developed between the Russian Nuclear Weapon Institutes and the U.S. fuel cell industry.

Together, the Russians and Americans have developed a concept to make the consortium successful: to leverage financial resources by providing a best match of technical resources to solve specific problems in fuel cell power development and to eliminate unknown/unplanned duplication of effort. In this concept, power users would communicate their needs to potential fuel cell manufacturers. Fuel suppliers would report their ability to provide and distribute suitable fuels for utilization by the manufacturers fuel cell plants. The potential fuel cell manufacturers would then inform the scientists and engineers of the technical problems that prevent rapid fuel cell commercialization. Lastly, the scientists and engineers would identify and utilize the proper technical resources to solve these technical problems. An important side benefit of this concept is that it will strongly support defense conversion goals by providing meaningful technical challenges for Russian and U.S. scientists previously engaged in the development of nuclear weapons.

\section{IMPLEMENTATION}

The concept is being implemented by means of an agreement between the United States Department of Energy (DOE) and the Russian Federation Ministry of Atomic Energy (MINATOM). This agreement is guided by the principles of the December 1993 Russian/American agreement on scientific and technical collaboration and specifically addresses fuel cell development. The mission and purposes of the consortium are given on the poster. A steering committee composed of representatives from the U.S. and Russian governments national laboratories, and industry prepared the agreement and supporting documents for the consortium. The major supporting documents are those describing the Russian/American Fuel Cell Consortium (RAFCO) Participants and the Project Proposal guidelines. Both of these documents are shown on the poster and are available along with the basic agreement at the RAFCO table. 
RAFCO will be operated by a Joint Committee selected from the participants and chaired by two representatives, one from DOE and one from MINATOM. Various subcommittees including the proposal guidance and evaluation committee will support the Joint Committee.

Intellectual property rights are recognized as an important concern and are covered in the agreement and supporting documents. The first cooperative projects to be implemented under the agreement have been identified by the steering committee and will be started as soon as the agreement is in place. A list of these projects in provided on the poster.

\section{FUNDING}

Primary funding will come from government sources, with both governments sharing costs. Private industry and other agencies are expected to provide funding for projects meeting their special interests.

\section{RELATED ACTIVITIES}

Joint ventures between U.S. industry and Russian entities are expected and encouraged to develop out of RAFCO activities. 